Marquette University

e-Publications@Marquette

4-1-2015

\title{
How Responsive Are EU Coal-Burning Plants to Changes in Energy Prices?
}

Andrew G. Meyer

Marquette University, andrew.meyer@marquette.edu

Grzegorz Pac

Alfred University

Published version. The B.E. Journal of Economic Analysis and Policy, Vol. 15, No. 3 (April 2015): 1481-1506. DOI. (C) 2015 De Gruyter. Used with permission. 


\title{
Topics
}

\section{Andrew Meyer* and Grzegorz Pac How Responsive Are EU Coal-Burning Plants to Changes in Energy Prices?}

\begin{abstract}
The European Union (EU) Emissions Trading System (ETS) has implicitly made it more expensive to burn coal relative to natural gas because coal has a higher carbon content. Therefore, it is important to understand how much plants reduce their coal usage in response to higher coal prices to assess the effectiveness of the ETS in reducing carbon emissions. We analyze a novel panel of coal-burning large combustion plants from a subsample of eight EU countries and found that, holding constant the natural gas price, a $1 \%$ increase in the coal price results in a $0.36 \%$ decrease in coal consumption. At current ETS prices, this implies that the average large combustion plant in our sample EU countries is burning $7 \%$ less coal than it would be absent in the ETS. This suggests that the ETS has significantly reduced carbon emissions from coalfired plants for the eight countries represented in our sample.
\end{abstract}

Keywords: climate policy, Europe, large combustion plants, coal JEL Classification: D24, Q41, Q48, Q54

DOI 10.1515/bejeap-2014-0159

\section{Introduction}

With the Emissions Trading System (ETS), the European Union (EU) began the world's largest market-based approach to reduce greenhouse gas emissions. ${ }^{1}$

1 There have been three phases to the program thus far. The first phase (2005-2007) covered the power sector and some heavy industry. The second phase (2008-2012) slightly expanded the reach of the program and the third phase (2013-2020) is set to add a wide range of industrial activity (Newell et al. 2013).

*Corresponding author: Andrew Meyer, Economics Department, College of Business Administration, Marquette University, 606 N. 13th Street, David Straz Hall, Milwaukee, WI 53233, USA, E-mail: andrew.g.meyer@marquette.edu

Grzegorz Pac, School of Business, Alfred University, 1 Saxon Dr., Alfred, NY 14802, USA, E-mail: pac@alfred.edu 
The ETS places an explicit price on emitting $\mathrm{CO}_{2}$ since a covered producer is legally required to hold a permit for each unit of $\mathrm{CO}_{2}$ emitted. It is well known that burning coal emits about twice as much $\mathrm{CO}_{2}$ relative to burning natural gas. Therefore, the ETS is akin to raising the price of coal relative to the price of natural gas. A logical question then becomes, "how will a range of industrial plants respond when the price of coal increases due to the ETS?" We would expect an overall net decrease in carbon emissions if plants reduce their coal usage since it is more carbon intensive than its substitutes, chiefly natural gas. Decreasing carbon emissions is exactly the stated goal of the ETS.

It is difficult to cleanly identify the impact of the ETS on coal usage by looking across plants because all plants of a similar type are subject to the same carbon price; there is one EU market for carbon. Furthermore, only plants of a certain type have been subject to the ETS in the first two phases of the program. However, we can gain intuition into how a range of large combustion plants respond to such a price on carbon by examining the changing demand for coal within plants as the price of coal changes over time. Utilizing a panel of EU large combustion plants spanning eight countries and six years, we estimate demand functions for coal. We find that, controlling for unobserved plant-level heterogeneity, demand for coal is inelastic with respect to the price of coal. Holding constant the price of natural gas, average coal usage decreases by around 0.31$0.36 \%$ with a $1 \%$ increase in the price of coal. However, we also find some evidence of heterogeneity among the plants. Specifically, plants that have the ability to burn coal or natural gas may be more responsive to changes in energy prices than coal plants that do not have the ability to burn natural gas.

We merge information about fuel prices and coal usage for over 250 plants across Austria, Belgium, Denmark, Finland, Italy, Poland, Portugal and the UK for the years 2004-2009. These are the only eight countries for which we can obtain coal price data. Thus, we have data for large coal-burning plants representing roughly one-third of the EU countries. We exploit differences in fuel prices over time within a country to identify the responsiveness of plant level coal usage to changes in price. Most of these plants are electricity generating plants or combined heat and power plants (CHPs) but we also have plants representing the sugar, paper, chemical, refinery and iron/steel industries. Furthermore, most of these coal-burning plants burn exclusively coal but some also burn natural gas.

We make several contributions to the literature with this work. First, we examine a range of large combustion plants rather than focusing solely on the electricity generation sector, which has been the focus of most previous work in this area. This should give us a more comprehensive representation of the demand for coal in the EU and therefore provide more insight into how the average coal burning plant responds to the ETS. Additionally, we use a sample 
of plants from eastern and western European countries rather than focusing on one country or region. Moreover, we utilize plant-level micro data on coal consumption rather than using aggregate data. This may be preferable since the decisions about how much fuel to use are made at the plant or firm level rather than the macro level. Lastly, we contribute to the growing literature on the effectiveness of the ETS.

Recent economic conditions have served to decrease the price of coal within Europe. In response, coal usage has been on the rise in many EU countries. ${ }^{2}$ Our results suggest that coal usage would have increased even further without the ETS. For example, at the recent ETS allowance price of $\$ 7.00 /$ ton, we would expect coal usage by the average EU large combustion plant in our sample countries to be about $7 \%$ less compared to a system with a $\$ 0$ price on carbon emissions. In terms of emissions, this would mean that $\mathrm{CO}_{2}$ emissions from the average coal-burning plant in our sample are approximately 100,000 tons per year less than what they would be without the ETS. Thus, overall, our results suggest that an economic instrument that puts a price on carbon, such as a tax or tradable permit system, can be effective in reducing coal usage and its associated $\mathrm{CO}_{2}$ emissions from large combustion plants in the short run. The net change in $\mathrm{CO}_{2}$ emissions from large combustion plants as a whole would depend upon what happens to natural gas consumption and the consumption of alternative energy sources as coal usage decreases.

\section{Methods}

\subsection{Previous Literature}

There is a growing literature on the impacts of the EU ETS and carbon taxes. For example, a group of papers examine the impacts on firm performance and competitiveness. Anger and Oberndorfer (2008) examine German firms and find that permit allocation did not significantly affect firm employment or performance. Demailly and Quirion (2008) analyze the iron and steel industry and find that there has not been a significant drop in competitiveness due to the ETS. Chan et al. (2013) examine the power and cement industries in addition to the iron and steel industry and find that the impact of the ETS varies by industry. Jaraite et al. (2014) examine Swedish plants and found that policies that put a price on carbon encourage environmental expenditure but not investment. Martin et al. (2014) found that carbon leakage risk is more related to carbon

2 See, for example, Kopalek and Raghuveer (2013). 
intensity than to trade exposure. Two other papers examine technological change in relation to a climate policy (Fontini and Pavan 2014; Martin et al. 2011). However, there is a gap in our understanding of how plants are likely to respond to the ETS insofar as their fuel usage.

A group of papers examine the fuel-switching behavior in response to changes in coal and other energy prices. Bopp and Costello (1990) analyze fuel switching in aggregate time series data from the United States using a trans-log model and estimate the own price elasticity of demand for coal at -0.264. Ko and Dahl (2001) study the US electricity generation industry and found, using a trans-log cost model on cross-sectional data, an estimated price elasticity of demand ranging from -0.16 to -0.57 across the plant types and specifications. They also found evidence that electricity plants do substitute between different fuel types. Pettersson et al. (2012) analyze the fuel-switching behavior in response to changes in fossil fuel prices for the western European power sector. They estimate a generalized Leontif cost function on data aggregated at the country level and do not find the price elasticity of demand to be statistically different from 0 or -1 . They do find statistically significant cross-price elasticities of demand between oil and gas, but not between coal and the other two fossil fuels. Soderholm (2001) also examined fuel switching in the western European power sector and finds evidence of switching behavior within multi-fired plants, between single-fired plants, and through conversions of existing plants. Estimating a trans-log cost function on a sample of 66 country-year observations from six countries, Belgium, Ireland, Italy, Netherlands, Spain and the United Kingdom, Soderholm (2001) finds own-price elasticities of coal ranging from -0.29 to 0.03 . However, standard errors are not reported for these estimates and Soderholm states that the "trans-log fuel demand system was not particularly consistent with its theoretical restrictions" (2001). This suggests that it is worth exploring other estimation strategies for identifying elasticities. Two other papers seek to estimate demand functions for coal at the macroeconomic level using time-series data. Masih and Masih (1996) estimate coal demand in China using a double-log model on macro data from 1953 to 1992 and find an estimated short-run price elasticity of demand of -0.83 . Chan and Lee (1997) also model the coal demand of China on a macro-level and find an estimated short-run price elasticity of demand of -0.255 .

Few studies utilize micro-level data to estimate firms' responses to changes in fuel prices. Tauchmann (2006) examines nine utilities in Germany's electricity generation industry from 1968 to 1998, but does not find evidence that fuel mix decisions are driven by fuel prices. Tauchmann (2006) argues that standard profit-maximizing or cost-minimizing models are not usually appropriate for highly regulated industries such as electricity because firms in these industries face restrictions other than price and production technology. Furthermore, Frondel and Schmidt (2002) show that elasticities of substitution from standard models such as the trans-log are not 
reliable. Therefore, in our analysis, we posit a reduced-form model that does not depend on strong assumptions often required to identify structural parameters. This is similar to the approach taken by Linn et al. (2014), in which they estimate a reduced-form utilization function to determine the effect of coal prices on utilization rates of US electricity producers. Using a panel of nearly all US coal-fired electricity generation plants for the years 1985-2009, Linn et al. (2014) estimate the elasticity of the utilization rate relative to the coal price at around -0.4 across several specifications.

\subsection{Data Description}

In order to estimate coal demand functions at the plant level, we need to merge data from several sources. Data on coal usage at the plant level for the years 2004-2009 come from the European Environmental Agency (EEA) (2012). The EEA has published data about the plants covered under the Large Combustion Plant Directive (LCPD). This directive covers plants of size 50 megawatt thermal (MWth) or larger, and each EU member country must track and report data on all such plants to the EEA. The LCPD data contain information on plant energy input, location, size and air emissions on an annual basis for 27 countries. ${ }^{3}$ The EEA has released two waves of the LCPD data, with the first wave covering 2004-2006 and the second wave covering 2007-2009. We match the plants from the two waves to form a six year panel. The second wave of the LCPD data identified the plant industry for most of the plants. For the remaining plants, we searched firm websites and other databases to identify the industry.

Energy price information at the plant level is not available so we instead obtain fuel prices for each country and year from the International Energy Agency (IEA). The IEA publishes a wide variety of information about energy prices in its publication and databases entitled, "Energy Prices and Taxes." 4 Specifically, we utilize the indices of energy end-use prices (including taxes) for industry. As stated by the IEA documentation, "For products where more than one price is available, a representative series is created for each country" (2013). We gather information on the indices for coal and natural gas. For the years

3 The countries include Greece, Poland, Romania, Portugal, Spain, United Kingdom, Netherlands, Belgium, Germany, France, Czech Republic, Italy, Cyprus, Estonia, Latvia, Lithuania, Finland, Hungary, Bulgaria, Malta, Denmark, Sweden, Austria, Luxembourg, Ireland, Slovakia and Slovenia. Information on energy input of individual plants is not available for Czech Republic, France and the Netherlands.

4 Full information on this publication and associated databases is available at: http://www.iea. org/statistics/topics/pricesandtaxes/. 
2004-2009, the IEA provides coal indices for 8 of the countries from the LCPD database including Austria, Belgium, Denmark, Finland, Italy, Poland, Portugal and the UK and natural gas indices for 14 countries from the LCPD database including Austria, Belgium, Estonia, Finland, Germany, Greece, Hungary, Ireland, Italy, Poland, Portugal, Slovakia, Spain and the UK.

The IEA states, "for coal, the industry index includes representative steam coal and coking coal" (2013). Furthermore, "Indices with the base year $2010=100$ were computed for each price series from prices in national currencies and then aggregated over product groups, sectors and countries. The Paasche formula is used for index computation. The weights used are the physical quantities consumed, as published in the OECD/IEA Energy Statistics of OECD countries" (2014). Thus, these price indices capture the prices that large combustion plants actually pay in each EU country during a given year. These indices are available in both nominal and real terms. "To calculate the real price index, the nominal prices are deflated with country-specific producer price indices $(2010=100)$ for the industry sector" $(2014)$. We focus our analysis on coal-burning large combustion plants. Therefore, we define our population to be coal-burning large combustion plants in Austria, Belgium, Denmark, Finland, Italy, Poland, Portugal and the UK for the years 2004-2009. ${ }^{5}$ Figure 1 plots the energy price indices for the eight sample countries from 2004-2009. While the long-term trend appears to be positive for most of the countries for both coal prices and natural gas prices, there is certainly variation in how fast the prices change and in how volatile the prices are over the sample period. Furthermore, there are short-term increases and decreases in the prices within all the countries. As we are interested in short-term consumption decisions by plants, it is this short-term variation in price within a country that provides the necessary variation for our analysis.

Table 1 shows the number of plants in our sample from each of these eight countries that burn coal in 2004. Altogether, within these 8 countries, we have an unbalanced panel of 274 coal-burning plants that report coal usage to the EEA over the years 2004-2009. ${ }^{6}$ Table 2 shows the evolution of the panel over the 6-year sample. The vast majority of the plants are burning only coal or only natural gas, with a small minority burning both fuel types. Table 3 exhibits the number of plant-year observations according to industry. As seen in the table,

5 These are the only countries for which coal prices are available.

6 There are 274 plants that report positive coal usage in at least 1 year. The number of plants in any given year reporting positive coal usage is less than 274 . There are 258 plants for which we have coal and natural gas prices because IEA does not have natural gas indices for Denmark. 
Austria

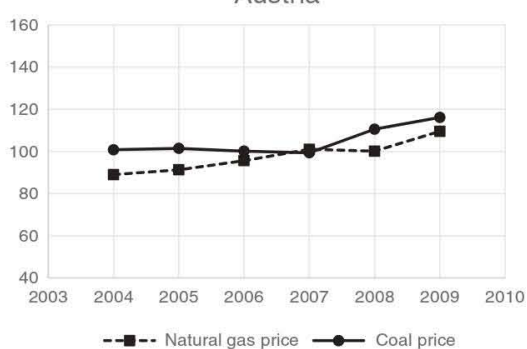

Denmark coal price
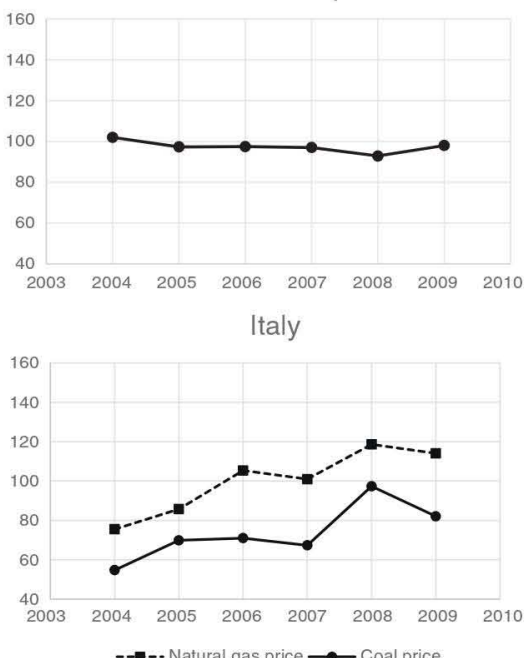

-- - Natural gas price $\longrightarrow$ Coal price

Portugal

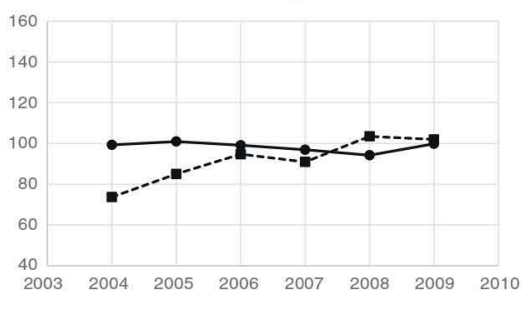

$\rightarrow-$ - Natural gas price $\longrightarrow$ Coal price
Belgium

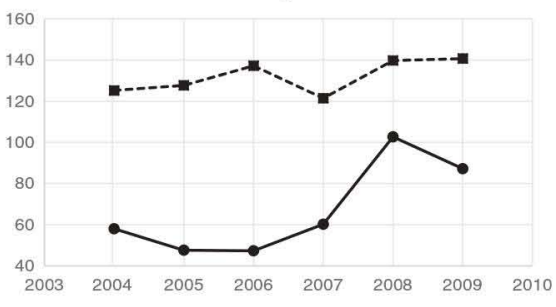

-- -. Natural gas price $\longrightarrow$ Coal price

Finland

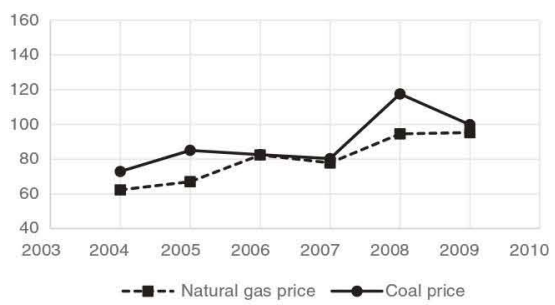

Poland

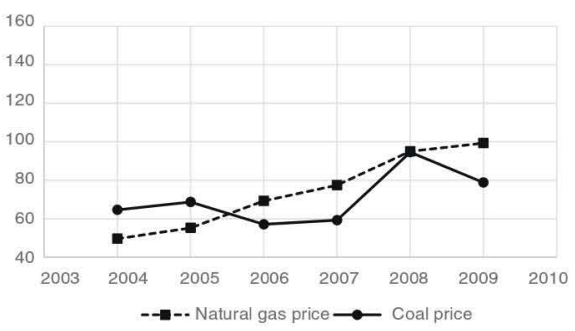

UK

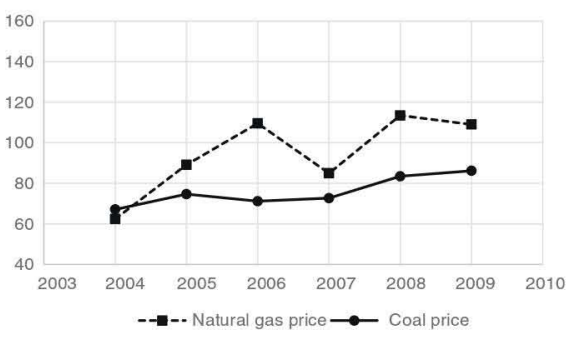

Figure 1: Fuel Prices by Country. 
Table 1: Plants by fuel type, 2004.

\begin{tabular}{lrr}
\hline Country & Plants burning only coal & Plants burning coal and natural gas \\
\hline Austria & 12 & 6 \\
Belgium & 11 & 9 \\
Denmark & 11 & 2 \\
Finland & 66 & 14 \\
Italy & 26 & 6 \\
Poland & 82 & 8 \\
Portugal & 3 & 0 \\
UK & 25 & 6 \\
\hline
\end{tabular}

Table 2: Plants by fuel usage over time.

\begin{tabular}{rrr}
\hline Year & Plants burning only coal & Plants burning coal and natural gas \\
\hline 2004 & 236 & 51 \\
2005 & 234 & 54 \\
2006 & 229 & 52 \\
2007 & 221 & 40 \\
2008 & 226 & 40 \\
2009 & 225 & 44 \\
\hline
\end{tabular}

Table 3: Plant-year observations by industry.

\begin{tabular}{lrr}
\hline Industry & Plants burning only coal & Plants burning coal and natural gas \\
\hline Sugar & 12 & 6 \\
Paper mill & 29 & 9 \\
Chemical & 24 & 9 \\
Refinery & 9 & 6 \\
Iron/steel & 12 & 4 \\
ESI & 522 & 92 \\
CHP & 716 & 130 \\
Heat & 3 & 1 \\
Other known & 6 & 0 \\
Other unknown & 38 & 24 \\
Total & 1,371 & 281 \\
\hline
\end{tabular}

ESI (Electricity Supply) and CHP are the most heavily represented industries in our sample.

Next, we gather information about the price of carbon emissions in the EU over this same time span. We obtain information about EUA futures and spot 
prices from the EEA (2011). This provides information about daily spot and futures prices of the European Union Allowances (EUAs). Each EUA entitles the holder to emit 1 ton of carbon dioxide equivalent gas. The spot price is likely the best measure of the short-run price on carbon, and therefore most relevant for day-to-day decision making about which fuels to burn. In contrast, the futures price is likely the best measure of the long-run price on carbon and would be the best measure for firms to consider when making their decisions about what type of plants to build or upgrade. For a given day, there are multiple futures contracts that could be traded. For example, in January 2005, one could have traded 2005, 2006 or 2007 EUA futures. In September 2007, one could have traded 2007, 2008, 2009, 2010, 2011 or 2012 EUA futures. The futures contracts of varying years differ slightly at any given point in time, but are heavily correlated. Thus, for any given date, we average the prices of the futures contracts that one could have traded. We average the daily prices over the span of the year to come up with annual carbon spot and futures prices. These carbon prices are common to all countries in the EU for a given year. In normal circumstances, the spot and futures prices will move in the same direction. However, the spot price diverged from the futures prices at several points throughout these seven years. The most notable divergence occurred in 2007 due to a series of events. As explained by Newell et al. (2013), initial limits were established without reliable data and modest in aim, it became apparent in 2006 that there was a considerable oversupply of permits, and allowances could not be banked for future phases of the program. Table 4 shows these prices that we construct for the years 2005-2009.

The share of renewable energy utilized in an economy can affect coal consumption because this can affect the merit order of plants. ${ }^{7}$ Thus, we gather the share of renewable energy in gross final energy consumption from Eurostat

Table 4: ETS carbon prices by year.

\begin{tabular}{lrr}
\hline Year & EUA spot price & EUA futures price \\
\hline 2005 & $€ 21.82$ & $€ 18.15$ \\
2006 & $€ 17.27$ & $€ 19.05$ \\
2007 & $€ 0.65$ & $€ 15.40$ \\
2008 & $€ 11.13$ & $€ 24.00$ \\
2009 & $€ 13.17$ & $€ 14.21$ \\
\hline
\end{tabular}

7 We thank an anonymous reviewer for making this point. 
at the country-year level. Finally, we gather information about economic activity at the country level from Eurostat (2014). Clearly, fuel use will increase when the economy is producing more goods and services so it is important to control for the level of output in the analysis. As our measure of macroeconomic activity, we utilize country-level real GDP per capita (measured in Euros). Table 5 presents summary statistics for all of our variables.

Table 5: Summary statistics.

\begin{tabular}{lccccr}
\hline Variable & Mean & Std. dev. & Min. & Max. & $\boldsymbol{n}$ \\
\hline Coal, TJ & $15,665.2$ & $30,094.5$ & 0.8 & $280,776.2$ & 1,371 \\
Natural gas, TJ & 143.84 & 869.40 & 0.00 & $12,521.18$ & 1,371 \\
Coal price & 79.92 & 17.04 & 47.34 & 117.51 & 1,371 \\
Natural gas price & 84.90 & 20.82 & 49.62 & 140.72 & 1,302 \\
EUA spot price & 12.94 & 7.08 & 0.65 & 21.82 & 1,135 \\
EUA futures price & 18.18 & 3.39 & 14.21 & 24.00 & 1,135 \\
MWth & $1,036.4$ & $1,652.0$ & 50.0 & $12,600.0$ & 1,336 \\
Real GDP/capita (thousand $€$ ) & 21.94 & 11.51 & 6.20 & 39.90 & 1,371 \\
Renewable energy share & 14.57 & 11.12 & 1.2 & 31.3 & 1,371 \\
\hline
\end{tabular}

\subsection{Conceptual Framework}

We are mainly interested in how large coal-burning plants respond to changing fuel prices in the short term. There are several testable hypotheses that emerge. First, the basic theory of the firm says that, as an input price increases, the firm will use less of that input. At the same time, coal is a crucial input for many of these plants because it is needed for the combustion process; they do not have the option of substituting a different fuel such as natural gas. Therefore, we may well expect that demand for coal will be inelastic with respect to price for many of these plants.

There is likely significant heterogeneity across plants in their responsiveness to changes in the price of coal relative to natural gas. For example, operators of brown coal burning power plants are often also the extractors of the nearby lignite reserves used to power the plant. These operators may well be much less responsive to changes in fuel prices than other operators who are more integrated with regional and global energy markets. Nevertheless, we note that we are most interested in the average plant responsiveness to changes in the coal price because this is most relevant for policymakers. That is, to assess the effectiveness of the ETS in reducing overall coal consumption of large combustion plants, we need to include plants representing the entire population of large combustion plants in our sample countries. 
Furthermore, multi-plant firms own many of these coal-burning plants. To take the example of the electricity supply industry, firms often own coal and natural gas fired power plants. As explained in Soderholm, "Changes in fossil fuel prices can change the merit order of plants using different fuels" (2001). Thus, the decision of which plants to dispatch on a given day will depend on the demand for electricity as well as the relative prices of the fuels. As coal increases in price, we would expect firms to scale back on electricity production from coalfired plants and ramp up production from natural gas plants. Similarly, as natural gas increases in price, we would expect firms to utilize their coal-fired plants more heavily. Price signals from natural gas and coal can be important to the decisions of plants even when the plant itself only has the ability to burn one specific type of fuel. That said, plants that do have the ability to switch between natural gas and coal should be more responsive to changes in price than plants that do not have the ability. Thus, we split the sample into two groups; the plants that never burn natural gas comprise one group and the plants that burn natural gas in at least one of the years make up the other group. Table 6 summarizes the characteristics of the two subgroups. Of the 184 plants in the subgroup that never burns natural gas, 173 are energy utilities. Of the 74 plants in the subgroup that do burn natural gas, 58 are energy utilities. The plants that never burn natural gas also tend to be somewhat larger than plants burning both fuels, both in terms of capacity and coal consumption.

As explained earlier, the ETS began in 2005. Placing a price on carbon effectively makes burning coal more expensive than burning natural gas since $\mathrm{CO}_{2}$ emissions are higher from coal. We examine annual coal usage, so the spot EUA price is likely the best measure of the price premium for burning coal relative to natural gas. Therefore, we predict that increasing spot EUA prices will

Table 6: Summary statistics of fuel subgroups.

\begin{tabular}{lrrrrr}
\hline Variable & Mean & Std. dev. & Min. & Max. & $n$ \\
\hline Plants burning coal and natural gas & & & & \\
Coal, TJ & $12,143.8$ & $20,870.3$ & 0.8 & $140,023.0$ & 358 \\
Natural gas, TJ & 550.85 & $1,635.78$ & 0.00 & $12,521.18$ & 358 \\
MWth & 914.7 & $1,504.4$ & 50.0 & $6,400.0$ & 348 \\
Energy utility & 0.80 & 0.40 & 0.00 & 1.00 & 358 \\
Plants never burning natural gas & & & & & \\
Coal, TJ & $16,909.7$ & $32,657.0$ & 1.1 & $280,776.2$ & $1,013.0$ \\
Natural gas, TJ & 0.00 & 0.00 & 0.00 & 0.00 & $1,013.00$ \\
MWth & $1,079.3$ & $1,699.6$ & 54.0 & $12,600.0$ & 988.0 \\
Energy utility & 0.94 & 0.23 & 0.00 & 1.00 & $1,013.00$ \\
\hline
\end{tabular}


lead to plants burning a smaller quantity of coal. It is uncertain whether increasing EUA futures prices will lead to immediate reductions in coal usage. It is more likely that one would observe EUA futures prices affecting the decision about what types of new plants to build.

\subsection{Empirical Strategy}

To test our hypotheses, we estimate demand functions for coal where we assume that demand for coal depends on the coal price and the natural gas price as well as other controls. ${ }^{8}$ Recall that most of the plants burn either coal or natural gas, but not both fuels. However, it is certain that many of these plants are owned by parent companies that operate both coal and natural gas plants. Thus, it is important to control for the price of natural gas in the analysis. We take the natural logs of all variables to facilitate an elasticity interpretation. We acknowledge that there likely is substantial unobserved heterogeneity across plants and that coal usage likely changes over time for many reasons that are unobservable to us. Thus, for our base specification, we have

$$
\begin{aligned}
\ln \text { coal }_{i t}= & \beta_{0}+\beta_{1} \ln \mathrm{CP}_{i t}+\beta_{2} \ln \mathrm{NP}_{i t}+\beta_{3} \ln \mathrm{MWth}_{i t}+\beta_{4} \mathrm{GDP} / \text { capita }_{i t} \\
& +\beta_{5} \mathrm{RES}_{i t}+\alpha_{i}+I_{t}+\varepsilon_{i t},
\end{aligned}
$$

where CP is the real coal price, NP is the real natural gas price, MWth is the thermal capacity of the plant, RES is the country-level renewable energy share, $\alpha_{i}$ are plantspecific time-invariant effects, $I_{t}$ are year fixed-effects and $\varepsilon_{i t}$ are iid error terms for plant $i$ in year $t$. If the plant-specific effects are correlated with the energy prices and constant over time, we should use the fixed-effects model to produce consistent parameter estimates. ${ }^{9}$ If, however, the plant-specific effects are uncorrelated with the energy prices, the random effects estimator will give consistent estimates and will be more efficient than the fixed effects estimator. We are using plant-level data on coal usage and country-level prices so, as long as the plants are small enough

8 If our dependent variable (coal consumption) is integrated and our energy prices are integrated, we could have a problem with spurious regression. We aggregate coal consumption to the country level to form a balanced panel and conduct a Harris-Tzavalis (HT) test using STATA's xtunitroot command. We reject the null of the coal consumption series containing unit roots with a $p$-value of 0.0008 and conclude this series is stationary.

9 There are certainly other plant level omitted explanatory variables that determine the level of coal consumption such as plant age and efficiency. We do not have any information on these variables. However, within a fixed-effects framework, these omitted variables will not bias the estimated coefficients of interest on the fuel prices as long as the omitted variables are not changing over time in ways that are correlated with fuel prices. 
relative to the overall coal demand within a country, the actions of one plant will not change the price variable very much. In other words, the price variable may well be largely exogenous to the plants. Nonetheless, there could be plant-specific effects that are correlated with the independent variables and the error term, so we estimate eq. [1] with both fixed effects and random effects models.

The EUA spot and futures prices vary only across years and not across plants or countries. Thus, it is not possible to identify a model with year fixed effects in this case. Nevertheless, we are interested in whether the spot and futures prices have a different effect on coal usage so we investigate a second model that controls for economic activity. Therefore, our model is,

$$
\begin{aligned}
\ln \text { coal }_{i t}= & \beta_{0}+\beta_{1} \ln \mathrm{CP}_{i t}+\beta_{2} \ln \mathrm{NP}_{i t}+\beta_{3} \ln \mathrm{MWth}_{i t}+\beta_{4} \mathrm{GDP} / \text { capita }_{i t} \\
& +\beta_{5} \ln \text { EUA_Spot }_{t}+\beta_{6} \ln \text { EUA_Futures }_{t}+\beta_{7} \mathrm{RES}_{i t}+\alpha_{i}+\varepsilon_{i t},
\end{aligned}
$$

where EUA_Spot is the EUA spot price, EUA_Futures is the EUA futures price, $\alpha_{i}$ are plant-specific time-invariant effects, and $\varepsilon_{i t}$ are iid error terms for plant $i$ in year $t$. Again, we estimate eq. [2] with both fixed effects and random effects models.

The inclusion of the country-level renewable energy share, RES, in eqs [1] and [2] is debatable. On one hand, this variable can control for some of the exogenous variation in country level energy policy. For example, renewable portfolio standards/renewables obligations in some sample countries legislate that a certain percentage of a country's electricity must come from renewable sources. Changes to these laws are exogenous to the decision-making of individual plants so, to the extent that the RES variable measures these laws, it is a valid exogenous control variable. In this case, the omission of the RES variable could bias our estimates because RES can affect the merit order of electricity plants. However, it can also be argued that the country-level renewable energy share is an outcome of the fuel choices of individual plants in a given country. This can especially be a concern for smaller countries where the electricity supply is more highly concentrated. In this case, the inclusion of the RES variable could bias our estimates. In light of these possibilities, we estimate specifications both with and without the RES variable. We report results for the models that include RES and note that estimates of other coefficients change only slightly when excluding RES. ${ }^{10}$

There are several econometric issues that merit attention given the nature of our data including correlated error terms and measurement error. Recall that the price variation is at the country level and the coal demand variation is at the plant

10 We conducted this robustness analysis for all results in the paper. 
level. Thus, there could be correlated errors for plants within a country for a given year. Ignoring this would result in biased standard error estimates. This is the classic Moulton problem (1986) and the appropriate method to produce consistent standard error estimates if errors were independent over time would be to cluster standard errors at the country-year level. However, there is likely also serial correlation within countries. For example, a negative economic shock in Italy in a given year is likely to persist over time and influence coal demand for plants in Italy in subsequent years. This serial correlation in clustered panels can also lead to inference problems if unaddressed. One appropriate solution is to cluster at the country level rather than the country-year level (Angrist and Pischke 2009). ${ }^{11}$ Therefore, we report STATA (2011) clustered standard errors at the country level for all regressions.

Ideally we would have data on the actual price paid by each plant rather than country level price data. However, to our knowledge, these data do not exist. With country level price data, we have measurement error in our energy price variables. We may expect that this measurement error has a mean that is close to 0 because the country level price from the IEA is formed by taking a representative average of the prices paid. Thus, within a given country, some plants will have actually paid more than the country average and some will have paid less than the average. So, the observations where we are using "too high" a coal price should about balance with the observations where we are using "too low" a coal price. If this is the only variable with measurement error, then we would have an attenuation bias. That is, the direction of the inconsistency of our estimate on the coefficient would be toward 0 . Even if there is measurement error on other variables, the direction of the inconsistency would still be toward 0 as long as the measurement errors on different regressors are independent (Cameron and Trivedi 2005). Thus, we view our estimates of the coefficients on the coal price and the natural gas price as lower bounds (in absolute value) of the true parameter values. This implies that the large combustion plants are at least as responsive to a change in the energy prices as we report. So, in reality, large combustion plants may cut their coal usage by an even greater amount when the price of coal increases.

A final concern is that our log-log specification drops the observations for which coal usage is zero. For multi-fuel plants that use coal in some years but not others, this creates an endogenous sample selection problem and we would understate their sensitivity to changes in the price of coal. This would bias our coefficient on coal price toward 0 . That is, to the extent that there is a sample

11 Hansen (2007) finds that STATA clustered standard errors are rather good at correcting for serial correlation in panel data, even with a relatively small number of clusters. 
selection problem, it would work against us finding statistically significant results. However, there are relatively few multi-fuel plants that burn coal in at least one year and report zero coal usage in any other year in our data. Only 37 of the 258 sample plants report both positive and zero coal usage throughout the sample period. As a robustness check, we estimate the model excluding these 37 plants.

\section{Results}

\subsection{Full Sample}

We begin by estimating eqs [1] and [2] using our full sample of 258 plants. Table 7 shows results for eq. [1]. We present results for both the fixed effects and random effects estimators for comparison, but note that a test of fixed versus random effects finds strong evidence to reject the random effects model. ${ }^{12}$ Therefore, the estimates from the random effects model are not consistent and we rely on the fixed effects estimates. Controlling for the size of the plant, a $1 \%$ increase in the price of coal is expected to lead to a $0.307-0.356 \%$ reduction in the amount of coal consumed. This coefficient is significantly different from 0 and also significantly different from 1 . Therefore, we conclude from this first set of regressions that coal demand is inelastic with respect to price. Furthermore, the cross-price elasticity between coal and natural gas is estimated between 0.402 and 0.514 and there is evidence that this cross-price elasticity is statistically different from 0 . Therefore, as the price of natural gas increases by $1 \%$, we expect coal usage to increase by around $0.4-0.5 \%$, indicating that there is substitution between the two fuels at the plant level. Coal usage increases within a plant as the capacity of the plant (MWth) increases. However, the relationship is not one-to-one; a $1 \%$ increase in plant capacity is associated with a $0.45-$ $0.46 \%$ increase in coal consumption in specifications (1) and (2) from Table 7.

Table 8 presents the results for eq. [2]. We once again find strong evidence to reject the random effects model so we focus on interpreting the fixed effects results. The estimated coefficients on ln Coal Price are about twice as large as the corresponding estimates from Table 7 (eq. [1]). We do not find significant results on either EUA price for any of the fixed effects regressions. This is perhaps not surprising; there is little variation to work with here since the EUA prices are common to all plants throughout the EU for a given year.

12 We utilize the STATA user-written xtoverid test (Schaffer and Stillman 2011) which uses the artificial regression approach described in Arellano (1993). This is the appropriate test in place of the Hausman test when using clustered standard errors. 
Table 7: Regression results for the full sample (eq. [1]).

\begin{tabular}{|c|c|c|c|c|}
\hline \multirow[t]{2}{*}{ Variables } & (1) & (2) & (3) & (4) \\
\hline & Fixed effects & Fixed effects & Random effects & Random effects \\
\hline \multirow[t]{2}{*}{ In Coal Price } & $-0.307^{\star \star}$ & $-0.356^{\star \star}$ & $-0.440^{\star \star \star}$ & $-0.397^{\star \star \star}$ \\
\hline & $(0.119)$ & $(0.142)$ & $(0.150)$ & $(0.116)$ \\
\hline \multirow[t]{2}{*}{ In Natural Gas Price } & $0.402^{\star}$ & $0.514^{\star \star}$ & $0.457^{\star \star \star}$ & 0.365 \\
\hline & $(0.201)$ & $(0.201)$ & $(0.170)$ & $(0.229)$ \\
\hline \multirow[t]{2}{*}{ In MWth } & $0.462^{\star \star}$ & $0.452^{\star \star \star}$ & $1.180^{\star \star *}$ & $1.143^{\star \star \star}$ \\
\hline & $(0.134)$ & $(0.139)$ & $(0.0767)$ & $(0.0885)$ \\
\hline \multirow[t]{2}{*}{ Real GDP/capita (th. €) } & & 0.0313 & & 0.00703 \\
\hline & & $(0.0292)$ & & $(0.00765)$ \\
\hline \multirow[t]{2}{*}{ Renewable energy share } & & 0.0613 & & -0.0119 \\
\hline & & $(0.0359)$ & & $(0.00949)$ \\
\hline \multirow[t]{2}{*}{ Constant } & $5.331^{\star \star \star}$ & $3.684^{\star \star \star}$ & $1.130^{\star \star}$ & $1.571^{\star \star}$ \\
\hline & $(0.676)$ & $(0.918)$ & $(0.551)$ & $(0.605)$ \\
\hline Year-fixed effects & Yes & Yes & Yes & Yes \\
\hline Observations & 1,300 & 1,300 & 1,300 & 1,300 \\
\hline Number of plants & 258 & 258 & 258 & 258 \\
\hline
\end{tabular}

Note: Robust standard errors in parentheses are clustered at the country level.

${ }^{\star \star *} p<0.01,{ }^{\star \star} p<0.05,{ }^{\star} p<0.1$.

Furthermore, not all plants were subject to the ETS regulations during our sample period. Recall that the first phase of the program was limited in scope so many of the plants would not have been factoring in the price of carbon.

The difference in the estimated demand elasticities with respect to coal price between Tables 7 and 8 can be explained with further examination of the time trend in coal consumption. In estimating eq. [1] (Table 7), we use 2004 as our omitted comparison year for the time-fixed effects. Coefficients on all other year fixed effects (2005-2009) are negative and statistically significant. Furthermore, the time-fixed effects coefficients increase in absolute magnitude for each successive year. This suggests that there was a negative trend in coal consumption across our sample countries over the sample period. At the same time, Figure 1 revealed that the long-term trend of coal prices was positive for most of our sample countries during this same time. Recall that we cannot identify the model in eq. [2] when including time-fixed effects. Thus, to the extent that GDP/Capita and the EUA prices do not capture shocks common to Europe in a given year, the coefficient on coal price will be biased upward (in absolute value) in eq. [2] (Table 8). That is, unobserved factors contributing to trends in coal consumption are misattributed to the price of coal in eq. [2], making it seem 
Table 8: Regression results for the full sample (eq. [2]).

\begin{tabular}{|c|c|c|c|c|c|}
\hline \multirow[t]{2}{*}{ Variables } & (1) & (2) & (3) & (4) & (5) \\
\hline & $\begin{array}{r}\text { Fixed } \\
\text { effects }\end{array}$ & $\begin{array}{r}\text { Fixed } \\
\text { effects }\end{array}$ & $\begin{array}{r}\text { Random } \\
\text { effects }\end{array}$ & $\begin{array}{r}\text { Random } \\
\text { effects }\end{array}$ & $\begin{array}{r}\text { Fixed } \\
\text { effects }\end{array}$ \\
\hline In Coal Price & $\begin{array}{l}-0.640^{\star} \\
(0.280)\end{array}$ & $\begin{array}{l}-0.657^{\star \star} \\
(0.265)\end{array}$ & $\begin{array}{l}-0.642^{\star \star} \\
(0.282)\end{array}$ & $\begin{array}{l}-0.600^{\star \star} \\
(0.275)\end{array}$ & $\begin{array}{l}-0.513^{\star} \\
(0.229)\end{array}$ \\
\hline In Natural Gas Price & $\begin{array}{r}0.159 \\
(0.251)\end{array}$ & $\begin{array}{l}0.0143 \\
(0.271)\end{array}$ & $\begin{array}{r}0.215 \\
(0.256)\end{array}$ & $\begin{array}{r}0.185 \\
(0.266)\end{array}$ & $\begin{array}{r}0.311 \\
(0.260)\end{array}$ \\
\hline In MWth & $\begin{array}{l}0.471^{\star \star \star} \\
(0.108)\end{array}$ & $\begin{array}{l}0.458^{\star \star \star} \\
(0.116)\end{array}$ & $\begin{array}{l}1.151^{\star \star \star} \\
(0.0614)\end{array}$ & $\begin{array}{l}1.141^{\star \star \star} \\
(0.0870)\end{array}$ & $\begin{array}{l}0.439^{\star \star} \\
(0.121)\end{array}$ \\
\hline In EUA_Spot & $\begin{array}{l}-0.0165 \\
(0.0233)\end{array}$ & $\begin{array}{r}0.0160 \\
(0.0207)\end{array}$ & $\begin{array}{l}-0.0186 \\
(0.0243)\end{array}$ & $\begin{array}{l}-0.0129 \\
(0.0238)\end{array}$ & $\begin{array}{r}-0.00761 \\
(0.0201)\end{array}$ \\
\hline In EUA_Future & $\begin{array}{r}0.308 \\
(0.181)\end{array}$ & $\begin{array}{r}0.139 \\
(0.150)\end{array}$ & $\begin{array}{c}0.321^{*} \\
(0.176)\end{array}$ & $\begin{array}{r}0.271 \\
(0.184)\end{array}$ & $\begin{array}{l}0.0815 \\
(0.148)\end{array}$ \\
\hline $\begin{array}{l}\text { Real GDP/capita } \\
\text { (th. } €)\end{array}$ & & $\begin{array}{l}0.0758^{* *} \\
(0.0237)\end{array}$ & & $\begin{array}{c}0.0122^{*} \\
(0.00648)\end{array}$ & $\begin{array}{l}0.0593^{* *} \\
(0.0210)\end{array}$ \\
\hline $\begin{array}{l}\text { Renewable energy } \\
\text { share }\end{array}$ & & $\begin{array}{l}0.00904 \\
(0.0268)\end{array}$ & & $\begin{array}{l}-0.00851 \\
(0.00799)\end{array}$ & $\begin{array}{r}0.0593 \\
(0.0360)\end{array}$ \\
\hline Constant & $\begin{array}{l}6.706^{\star \star \star} \\
(0.537)\end{array}$ & $\begin{array}{l}6.185^{\star \star * *} \\
(0.586)\end{array}$ & $\begin{array}{l}2.167^{\star \star \star} \\
(0.311)\end{array}$ & $\begin{array}{l}2.173^{\star \star \star} \\
(0.360)\end{array}$ & $\begin{array}{c}153.805^{\star} \\
(69.54)\end{array}$ \\
\hline Time trend & & & & & $\begin{array}{l}-0.0746^{\star} \\
(0.0352)\end{array}$ \\
\hline Observations & 1,075 & 1,075 & 1,075 & 1,075 & 1,075 \\
\hline Number of plants & 253 & 253 & 253 & 253 & 253 \\
\hline
\end{tabular}

Note: Robust standard errors in parentheses are clustered at the country level.

${ }^{\star \star \star} p<0.01,{ }^{\star \star} p<0.05,{ }^{\star} p<0.1$.

as though plants are more sensitive to short-term movements in the price of coal than they actually are. If this argument holds true, adding a linear time trend should help to reduce the extent of the bias. This is precisely what we see in Column 5 for the plant-fixed effects model with a linear time trend. ${ }^{13}$ Hence, these results without time-fixed effects are likely unreliable and we proceed considering only results from eq. [1] (Table 7).

\subsection{Subsample of Only Energy Utilities}

One issue for the comparability of our results is that our sample includes plants from sectors other than the energy industry, whereas most previous work

13 Random effects results adjust similarly and are available upon request. 
Table 9: Regression results for energy utilities only.

\begin{tabular}{|c|c|c|c|c|}
\hline \multirow[t]{2}{*}{ Variables } & (1) & (2) & (3) & (4) \\
\hline & Fixed effects & Fixed effects & Random effects & Random effects \\
\hline \multirow[t]{2}{*}{ In Coal Price } & $-0.325^{\star}$ & $-0.353^{\star}$ & $-0.456^{\star \star \star}$ & $-0.422^{\star \star \star}$ \\
\hline & $(0.136)$ & $(0.146)$ & $(0.161)$ & $(0.119)$ \\
\hline \multirow[t]{2}{*}{ In Natural Gas Price } & 0.370 & $0.514^{\star}$ & $0.415^{\star \star}$ & 0.349 \\
\hline & $(0.242)$ & $(0.231)$ & $(0.197)$ & $(0.265)$ \\
\hline \multirow[t]{2}{*}{ In MWth } & $0.471^{\star \star}$ & $0.466^{\star \star}$ & $1.183^{\star \star \star}$ & $1.154^{* * *}$ \\
\hline & $(0.144)$ & $(0.144)$ & $(0.0698)$ & $(0.0885)$ \\
\hline \multirow[t]{2}{*}{ Real GDP/capita (th. €) } & & 0.0126 & & 0.00454 \\
\hline & & $(0.0279)$ & & $(0.00839)$ \\
\hline \multirow[t]{2}{*}{ Renewable energy share } & & $0.0696^{\star}$ & & -0.00840 \\
\hline & & $(0.0345)$ & & $(0.0110)$ \\
\hline \multirow[t]{2}{*}{ Constant } & $5.545^{\star \star \star}$ & $3.878^{\star \star \star}$ & $1.358^{\star \star \star}$ & $1.690^{\star \star *}$ \\
\hline & $(0.656)$ & $(0.963)$ & $(0.482)$ & $(0.685)$ \\
\hline Year-fixed effects & Yes & Yes & Yes & Yes \\
\hline Observations & 1,179 & 1,179 & 1,179 & 1,179 \\
\hline Number of plants & 231 & 231 & 231 & 231 \\
\hline
\end{tabular}

Note: Robust standard errors in parentheses are clustered at the country level.

${ }^{\star \star \star} p<0.01,{ }^{\star \star} p<0.05,{ }^{\star} p<0.1$.

concentrates on the energy sector. Therefore, we also analyze the subsample of large combustion plants in the energy industry. ${ }^{14}$ As shown in Table 9, the main results on the energy price variables remain statistically significant with only slight changes in the estimated coefficients. Thus, we are reasonably confident that our results are not being driven by non-energy sector plants.

\subsection{Analysis by Fuel-Switching Capabilities}

As covered in the data description, some of the sample plants burn both coal and natural gas over the 6 years of the panel while some plants never burn natural gas. One would expect that plants with the capability to burn either fuel would be more sensitive to changes in the two fuel prices. Here, we split the sample into the two subgroups and estimate eq. [1] utilizing the same fixed effects model that we run on the full sample. Table 10 shows the results for these two subgroups. As would be expected, the point estimates

14 We define the energy industry to be all ESI and CHP plants. 
Table 10: Regression results, split by fuel-switching capability.

\begin{tabular}{|c|c|c|c|c|}
\hline \multirow[t]{2}{*}{ Variables } & (1) & (2) & (3) & (4) \\
\hline & \multicolumn{2}{|c|}{ Plants burning coal and natural gas } & \multicolumn{2}{|c|}{ Plants never burning natural gas } \\
\hline In Coal Price & $\begin{array}{l}-0.375^{\star \star \star} \\
(0.0875)\end{array}$ & $\begin{array}{l}-0.399^{\star \star} \\
(0.148)\end{array}$ & $\begin{array}{l}-0.176 \\
(0.142)\end{array}$ & $\begin{array}{l}-0.268 \\
(0.158)\end{array}$ \\
\hline $\begin{array}{l}\text { In Natural Gas } \\
\text { Price }\end{array}$ & $\begin{array}{l}0.590^{\star \star} \\
(0.189)\end{array}$ & $\begin{array}{l}0.595^{\star \star} \\
(0.195)\end{array}$ & $\begin{array}{r}0.295 \\
(0.333)\end{array}$ & $\begin{array}{r}0.517 \\
(0.336)\end{array}$ \\
\hline In MWth & $\begin{array}{r}0.0174 \\
(0.0672)\end{array}$ & $\begin{array}{l}-0.0703 \\
(0.0762)\end{array}$ & $\begin{array}{l}0.604^{\star \star * *} \\
(0.145)\end{array}$ & $\begin{array}{l}0.622^{\star \star \star} \\
(0.135)\end{array}$ \\
\hline $\begin{array}{l}\text { Real GDP/capita } \\
\text { (th. €) }\end{array}$ & & $\begin{array}{c}0.0850^{\star} \\
(0.0402)\end{array}$ & & $\begin{array}{r}0.0131 \\
(0.0240)\end{array}$ \\
\hline $\begin{array}{l}\text { Renewable energy } \\
\text { share }\end{array}$ & & $\begin{array}{r}0.0353 \\
(0.0382)\end{array}$ & & $\begin{array}{l}0.0860^{*} \\
(0.0382)\end{array}$ \\
\hline Constant & $\begin{array}{l}7.291^{\star \star \star} \\
(1.165)\end{array}$ & $\begin{array}{l}5.853^{\star \star \star *} \\
(0.684)\end{array}$ & $\begin{array}{l}4.398^{\star \star \star} \\
(1.115)\end{array}$ & $\begin{array}{r}2.333 \\
(1.272)\end{array}$ \\
\hline Year-fixed effects & Yes & Yes & Yes & Yes \\
\hline Observations & 339 & 339 & 961 & 961 \\
\hline Number of plants & 74 & 74 & 184 & 184 \\
\hline
\end{tabular}

Note: Robust standard errors in parentheses are clustered at the country level.

All results are from the plant-fixed effects model. ${ }^{* \star} p<0.01,{ }^{* *} p<0.05,{ }^{*} p<0.1$.

are larger in magnitude for the plants that report burning both natural gas and coal. Furthermore, the coefficients on coal price and natural gas price are statistically different from 0 for the plants that burn both natural gas and coal whereas the coefficients are not different from 0 for the subgroup that never burns natural gas. We conduct a Wald test for differences in the coefficients on ln Coal Price from the two subsamples and fail to reject the null of equality at conventional levels ( $p$-value $=0.192) .{ }^{15}$ Also, the point estimates of the coefficients on the energy prices for the plants that never burn natural gas are of the same sign as in the other results. This is consistent with the idea that there may be some fuel switching that occurs at the firm level even when individual plants do not have the ability to switch fuels, but not enough for us to find a statistically significant effect with our sample size. Given that $94 \%$ of these plants that burn only coal are energy utilities, the fuel switching is likely related to changing the merit order of electricity-producing plants.

15 We implement this test using STATA's (2011) seemingly unrelated regression (suest) framework, clustering at the country level. 


\subsection{Robustness Check on Sample Selection}

As a final robustness check, we exclude the plants that report positive coal consumption in at least one year and 0 coal consumption in at least one year; this drops 37 plants from the analysis. Again, the concern here is that we could have endogenous sample selection because multi-fuel plants decide whether or not to burn a nonzero amount of coal in each sample year, and should they choose to not burn any coal, our log-log specification will exclude them from the sample. Table 11 shows results for this reduced sample. The results in column 1 are quite similar to those found in column 2 of Table 7 for the full sample. The point estimate on ln Coal Price is slightly larger in magnitude for this reduced sample compared to the full sample, consistent with the idea that any endogenous sample selection would bias our coefficient toward 0 in the full sample analysis. The same pattern is seen for the plants that burn natural gas and coal as well. In summary, the responsiveness of coal burning large combustion plants to changes in energy prices appears robust to potential sample selection issues.

Table 11: Regression results for subgroup of plants always reporting positive coal usage.

\begin{tabular}{|c|c|c|c|}
\hline \multirow[t]{2}{*}{ Variables } & (1) & (2) & (3) \\
\hline & $\begin{array}{r}\text { All plants in } \\
\text { subgroup }\end{array}$ & $\begin{array}{r}\text { Plants burning coal and } \\
\text { natural gas }\end{array}$ & $\begin{array}{r}\text { Plants never burning } \\
\text { natural gas }\end{array}$ \\
\hline \multirow[t]{2}{*}{ In Coal Price } & $-0.361^{*}$ & $-0.481^{\star *}$ & -0.209 \\
\hline & $(0.149)$ & $(0.147)$ & $(0.140)$ \\
\hline \multirow[t]{2}{*}{ In Gas Price } & 0.440 & $0.577^{\star \star \star}$ & 0.341 \\
\hline & $(0.241)$ & $(0.126)$ & $(0.379)$ \\
\hline \multirow[t]{2}{*}{ In MWth } & $0.564^{\star \star \star}$ & -0.0609 & $0.750^{\star \star \star}$ \\
\hline & $(0.0732)$ & $(0.0714)$ & $(0.141)$ \\
\hline \multirow{2}{*}{$\begin{array}{l}\text { Real GDP/capita } \\
\text { (th. } € \text { ) }\end{array}$} & 0.0309 & $0.0942^{\star}$ & 0.0125 \\
\hline & $(0.0231)$ & $(0.0438)$ & $(0.0170)$ \\
\hline \multirow{2}{*}{$\begin{array}{l}\text { Renewable energy } \\
\text { share }\end{array}$} & 0.0593 & 0.0291 & 0.0710 \\
\hline & $(0.0362)$ & $(0.0333)$ & $(0.0395)$ \\
\hline \multirow[t]{2}{*}{ Constant } & $3.458^{\star \star \star}$ & $5.742^{\star \star \star}$ & 2.308 \\
\hline & $(0.706)$ & $(0.648)$ & $(1.973)$ \\
\hline Year-fixed effects & Yes & Yes & Yes \\
\hline Observations & 1,193 & 290 & 903 \\
\hline Number of plants & 221 & 55 & 166 \\
\hline
\end{tabular}

Note: Robust standard errors in parentheses are clustered at the country level. All results are from the plant-fixed effects model. ${ }^{\star \star \star} p<0.01,{ }^{\star \star} p<0.05,{ }^{\star} p<0.1$. 


\section{Discussion}

We have shown that large coal combustion plants in Europe are inelastic in their demand for coal and tend to increase coal consumption when the price of natural gas increases relative to the price of coal. In this section, we explore the magnitude of our results given the prevailing economic conditions in Europe. Note that the ETS carbon price is not reflected in the prices we have used from the EIA. Therefore, we need to be clear about our assumptions on plant behavior. We assume that firms are pricing in the cost of burning carbon over and above the prices reflected in the EIA data. That is, we assume that plants consider how much they will have to pay for the EUAs when they make their fuel purchase decisions. All of the following analysis is based on the average results found from the full sample. We have shown that there is heterogeneity among plants in their responsiveness to changes in energy prices. Furthermore, the conversion factors that we use are averages so these estimates are meant to give a rough idea of the economic scale of the average results.

We use the following logic in order to link changes in the EUA price to changes in coal usage. Whenever the EUA price increases (decreases), the implicit price of coal relative to natural gas increases (decreases) because coal is a more carbon intensive fuel than is natural gas. We use conversion factors to determine how much carbon dioxide is released from one unit of energy for both coal and natural gas. This allows us to get an idea of how much it costs above the market price of the fuel itself to burn one unit of coal or one unit of natural gas at current EUA prices. We then use this information to determine how much the implicit prices of coal and natural gas have changed. Finally, we use the results of our econometric analysis to translate these changes in the implicit prices to changes in coal usage.

According to the EIA, 3.67 tons of carbon dioxide contain one ton of carbon. Also, depending on the type, coal ranges from approximately $60 \%$ to $80 \%$ carbon content; we assume a midpoint of $70 \%$ for this analysis. Thus, an EUA spot price of $€ 7.00$ per ton of $\mathrm{CO}_{2}$ would translate into approximately $€ 18.00$ per ton of coal. Relative to an EU spot price of $€ 70.00$ per ton of coal, this represents about a $25 \%$ addition to the implicit price of coal. Likewise, using EPA conversion factors (2014), the recent EUA spot price of $€ 7.00$ per ton of $\mathrm{CO}_{2}$ is equivalent to $€ 0.37 /$ MMBtu of natural gas. At the EU import price on natural gas of $€ 8.90 / \mathrm{MMBtu}$, a EUA spot price of $€ 7.00$ per ton of $\mathrm{CO}_{2}$ has increased the implicit price of natural gas by $4.1 \%$. A $10 \%$ increase in the price of coal would be approximately equivalent to a EUA spot price of $€ 2.80$ per ton of $\mathrm{CO}_{2}$ and a $10 \%$ increase in the price of natural gas would be approximately equivalent to a EUA spot price of 
$€ 17$ per ton of $\mathrm{CO}_{2}$. Thus, using the point estimates from Column 2 of Table 7, the net effect of a $€ 7.00$ per ton price on $\mathrm{CO}_{2}$ would be equal to $-0.356 \times 25+0.514$ $\times 4.1=-6.79 \%$. That is, as a rough estimate and on average, we expect that large coal-burning plants in our sample countries are today using approximately $7 \%$ less coal than they would be using absent the EU ETS.

Next, we investigate the implications for changes in carbon dioxide emissions due to this decrease in coal consumption. Given the information from the EIA, and assuming complete combustion of the coal, we can expect that each unit of coal burned will lead to 2.59 units of carbon dioxide. The average coalburning plant in our sample burns $15,665.2 \mathrm{TJ}$, which is equivalent to about 534,510 tons of coal on an annual basis. A $7 \%$ reduction in the amount of coal consumed would be a reduction of 37,416 tons of coal for the average plant in our sample. Therefore, we expect a carbon price of $€ 7.00$ per ton to save on the order of 96,907 tons of $\mathrm{CO}_{2}$ for the average plant from reduced coal usage. However, this is surely not the net effect of the policy. Some of the reduction in emissions from coal will be offset by an increase in emissions from natural gas and other carbon emitting fuels. The extent of the offsetting increase in emissions from these other fuel sources in important to study, but beyond the scope of this paper.

The share of overall EU carbon emissions caused by large combustion plants is sizeable. A report from the EU Integrated Pollution Prevention and Control Bureau (Best Available Techniques Reference Document for the Large Combustion Plants, 2013) states that large combustion plants accounted for $65 \%$ of the $\mathrm{CO}_{2}$ released from all plants covered by the Industrial Emissions Directive in the EU-15 in 2001, as reported by the European Pollutant Release and Transfer Register. While clearly not all EU large combustion plants burn coal, this helps to give a magnitude to the carbon emissions from large combustion plants relative to all other plants. Also, recall that the majority of the plants in our sample are electricity generating plants or CHPs. Restricting attention to the electricity and heat production industries in the EU-27, 65.8\% of total industry $\mathrm{CO}_{2}$ emissions were a result of burning coal in 2011 (Mandl, 2013). Therefore, reducing the amount of coal that is burned by large combustion plants could have a substantial effect on overall $\mathrm{CO}_{2}$ emissions within our sample countries.

\section{Conclusion and Policy Implications}

It is important to understand how coal-burning plants respond to changes in energy prices for a variety of reasons. Coal producers would want to know this 
information in planning for the future. Also, one of the main uses of coal is for producing electricity. Governments hold significant concern about electricity for political and economic reasons; therefore governments would be interested in knowing how plants respond to policies that add to the price of coal relative to natural gas. Finally, the EU has formulated public policy, namely the ETS, to reduce the amount of carbon emissions. The effectiveness of the EU ETS program will depend in part upon how responsive combustion plants are to increases in the price of carbon-intensive fuels.

One significant challenge in assessing the response to increases in the price of carbon via the ETS is that there is one ETS price throughout the entire EU. Thus, we cannot rely on cross-sectional variation in the price of carbon. Also, any other factors that are changing at the same time as the ETS and affecting carbon prices would confound our estimates. We avoid this problem by matching plant-level coal usage with coal prices that vary across eight countries over a period of 6 years and controlling for time effects. Plant responsiveness to changes in the coal price then provides insight into how the ETS is affecting coal usage throughout our subsample of the EU, assuming that plant decision makers rationally factor in the price of the carbon permits when making their fuel purchase decisions.

Coal usage has actually been on the rise in the EU, which has led some to conclude that the ETS is ineffective in this area. However, our estimates suggest that coal usage would have increased even more absent the ETS. In our preferred specification, we find that coal usage by large combustion plants in our sample countries decreases by around $0.36 \%$ when the price of coal increases by $1 \%$, holding constant the price of natural gas. At current coal prices and EUA prices, this suggests that coal usage by large combustion plants in our sample countries is about $7 \%$ lower than what it would be without the carbon price created through the ETS. Insofar as policymakers are concerned with reducing coal usage, these results should be informative. Although beyond the scope of this paper, there are other potential political and economic implications of reducing coal usage. For example, further research could investigate employment, revenue, and profit implications due to an increased relative price of coal.

Our results suggest that the ETS has likely had a sizeable effect on the carbon emissions from coal-burning large combustion plants in the EU. To understand the net effect of this policy, further research is needed on how much substitution has occurred from burning coal to burning other carbon intensive fuels such as natural gas. However, since coal has higher carbon content than natural gas, it is likely that carbon emissions have decreased on the net even if there was substantial substitution from burning coal to burning natural gas. Furthermore, we find some evidence that plants with the ability to burn coal or natural gas are 
more responsive to changes in fuel prices than are plants having only the ability to burn coal, as would be expected. But, we cannot rule out fuel switching that occurs at the firm level even when individual plants do not have the ability to switch fuel; this most likely occurs through changing the merit order of plants as one fuel becomes more expensive relative to the other. If one could get data providing both firm and plant information, it would be interesting to research just how much fuel switching occurs at the firm level.

Our analysis herein is focused on the short-run but the long-run effects of a carbon price on large combustion plants also deserve more attention. For example, how does investment in large combustion plants change in response to a carbon price? And, at what carbon price do firms decide to completely shut down coal burning plants and replace them with natural gas or another fuel source? These questions will be important to address as more data become available in the coming years. It is also important to investigate the behavior of coal-burning plants in countries that are not part of our sample due to a lack of coal price data to see how well the results generalize to the EU at large. We hope that researchers are inspired to look more closely into these important issues so that we can have a more comprehensive understanding of the impacts of the ETS.

\section{References}

Anger, N., and U. Oberndorfer. 2008. "Firm Performance and Employment in the EU Emissions Trading Scheme: An Empirical Assessment for Germany." Energy Policy 36: 12-22.

Angrist, J.D., and J. Pischke. 2009. Mostly Harmless Econometrics: An Empiricist's Companion. Princeton, NJ and Oxford: Princeton University Press.

Arellano, M. 1993. "On the Testing of Correlated Effects with Panel Data." Journal of Econometrics 59: 87-97.

Best Available Techniques (BAT) Reference Document for the Large Combustion Plants. 2013. Joint Research Centre, Institute for Prospective Technological Studies, Sustainable Production and Consumption Unit, European IPPC Bureau.

Bopp, A.E., and D. Costello. 1990. “The Economics of Fuel Choice at U.S. Electric Utilities.” Energy Economics 12: 82-88.

Calculations and References. 2014. US EPA. Accessed June 1, 2014. http://www.epa.gov/ cleanenergy/energy-resources/refs.html.

Cameron, A.C., and P.K. Trivedi. 2005. Microeconometrics: Methods and Applications. Cambridge: Cambridge University Press.

Chan, H.L., and S.K. Lee. 1997. "Modelling and Forecasting the Demand for Coal in China." Energy Economics 19: 271-87.

Chan, H.S., S. Li, and F. Zhang. 2013. "Firm Competitiveness and the European Union Emissions Trading Scheme." Energy Policy 63: 1056-64.

Demailly, D., and P. Quirion. 2008. "European Emission Trading Scheme and Competitiveness: A Case Study on the Iron and Steel Industry." Energy Economics 30: 2009-27.

Energy Prices and Taxes: Documentation for Beyond 2020 Files. 2013. IEA. 
Eua Future Prices 2005-2011. October 7, 2011. EEA. Accessed November 1, 2013. http://www. eea.europa.eu/data-and-maps/figures/eua-future-prices-200520132011.

Fontini, F., and G. Pavan. 2014. "The European Union Emission Trading System and Technological Change: The Case of the Italian Pulp and Paper Industry." Energy Policy 68: 603-07.

Frondel, M., and C.M. Schmidt. 2002. "The Capital-Energy Controversy: An Artifact of Cost Shares?" Energy Journal 23: 53-79.

Hansen, C.B. 2007. "Asymptotic Properties of a Robust Variance Matrix Estimator for Panel Data When T Is Large" Journal of Econometrics 141: 597-620.

Jaraite, J., A. Kazukauskas, and T. Lundgren. 2014. "The Effects of Climate Policy on Environmental Expenditure and Investment: Evidence from Sweden." Journal of Environmental Economics and Policy 3: 148-66.

Ko, J., and C. Dahl. 2001. "Interfuel Substitution in US Electricity Generation." Applied Economics 33: 1833-43.

Kopalek, M., and T. Raghuveer. 2013. 2013-last update, Multiple Factors Push Western Europe to Use Less Natural Gas and More Coal. ElA. Accessed April 4, 2014. www.eia.gov/ todayinenergy/detail.cfm?id=13151.

Linn, J., E. Mastrangelo, and D. Burtraw. 2014. "Regulating Greenhouse Gases from Coal Power Plants Under the Clean Air Act." Journal of the Association of Environmental and Resource Economists. 1: 97-134.

Mandl, N. 2013. Annual European Union greenhouse gas inventory 1990-2011 and inventory report 2013: Submission to the UNFCCC Secretariat. 8/2013. EEA.

Martin, R., M. Muûls, L.B. De Preux, and U.J. Wagner. 2014. "On the Empirical Content of Carbon Leakage Criteria in the EU Emissions Trading Scheme." Ecological Economics 105: 78-88.

Martin, R., L.B.D. Preux, and U.J. Wagner. 2011. "The Impacts of the Climate Change Levy on Manufacturing: Evidence from Microdata." National Bureau of Economic Research Working Paper Series, No. 17446.

Masih, R., and A.M.M. Masih. 1996. "Stock-Watson Dynamic OLS (DOLS) and Error-Correction Modelling Approaches to Estimating Long- and Short-Run Elasticities in a Demand Function: New Evidence and Methodological Implications from an Application to the Demand for Coal in Mainland China." Energy Economics 18: 315-34.

Moulton, B.R. 1986. "Random Group Effects and the Precision of Regression Estimates.” Journal of Econometrics 32: 385-97.

Newell, R.G., W.A. Pizer, and D. Raimi. 2013. "Carbon Markets 15 Years after Kyoto: Lessons Learned, New Challenges.” Journal of Economic Perspectives 27: 123-46.

Pettersson, F., P. Soderholm, and R. Lundmark. 2012. "Fuel Switching and Climate and Energy Policies in the European Power Generation Sector: A Generalized Leontief Model." Energy Economics 34: 1064-73.

Plant-by-Plant Emissions of SO2, NOx, and Dust and Energy Input of Large Combustion Plants Covered by Directive 2001/80/EC. 2012. EEA. Accessed November 1, 2013. http://www.eea. europa.eu/data-and-maps/data/plant-by-plant-emissions-of-so2-nox-and-dust-andenergy-input-of-large-combustion-plants-covered-by-directive-2001-80-ec-1\#tab-metadata.

Prices and Taxes Statistics. 2014. IEA. Accessed January 10, 2014. http://www.iea.org/statistics/topics/pricesandtaxes/.

Real GDP Per Capita. Eurostat. 2014. Accessed January 10, 2014. http://ec.europa.eu/eurostat/data/database. 
Schaffer, M.E., and S. Stillman. 2011. 11/02-last update, XTOVERID: Stata module to calculate tests of overidentifying restrictions after xtreg, xtivreg, xtivreg2, xthtaylor.

Soderholm, P. 2001. "Fossil Fuel Flexibility in West European Power Generation and the Impact of System Load Factors." Energy Economics 23: 77-97.

StataCorp. 2011. Stata Statistical Software: Release 12. College Station, TX: StataCorp LP.

Tauchmann, H. 2006. "Firing the Furnace? An Econometric Analysis of Utilities' Fuel Choice." Energy Policy 34: 3898-909. 